\title{
COMPARISON OF THREE METHODS BASED ON ENDOSCOPIC GASTRIC BIOPSIES FOR DIAGNOSIS OF Helicobacter pylori ACTIVE INFECTION IN A CLINICAL SETTING
}

\author{
Gabriel ARISMENDI-MORILLO ${ }^{1}$, Ileana HERNÁNDEZ ${ }^{1}$, Edgardo MENGUAL ${ }^{1}$, \\ Alisbeth FUENMAYOR ${ }^{2}$, Gisela ROMERO ${ }^{3}$ and Maribel LIZARZÁBAL ${ }^{3}$
}

\begin{abstract}
Context - The correct diagnosis and effective treatment of Helicobacter pylori gastric infection are essential in controlling this infection. Objective - To compare the diagnostic value of three tests based in endoscopic gastric biopsies histopathological evaluation with hematoxylin-eosin (H-E) staining, urease rapid test and microbiological culture for detecting Helicobacter pylori active infection, in order to make recommendations for daily clinical practice. Methods - Gastric biopsies from 115 adult patients ( 85 female/30 male) were obtained by upper gastrointestinal endoscopy and studied by histopathological evaluation with H-E (antrum-corpus), urease test in 2 hours (antrum) and microbiological culture (antrum). Results - Helicobacter pylori active infection was diagnosed in $67 \%$ of patients. Helicobacter pylori active infection was detected by histopathological evaluation with H-E, urease test and microbiological culture in $87 \%, 79 \%$ and $70 \%$ of the positive cases, respectively. There were significant differences when histopathological evaluation with H-E and urease test rapid test when compared with microbiological test $(P<0.01)$. There was no significant difference between histopathological evaluation with H-E and urease test $(P=0.7)$. The kappa index of agreement for histopathological evaluation with $\mathrm{H}$-E/urease test was 0.56 , histopathological evaluation with $\mathrm{H}-\mathrm{E} /$ microbiological culture 0.6 , and urease test/microbiological culture 0.64 . Conclusions - In a hospital setting like the one studied, histopathological evaluation with H-E and urease test are the most recommended tests for diagnosis of Helicobacter pylori active infection based in endoscopic biopsies. If pathological information of gastric lesions will be required, histopathological evaluation with H-E is essential. Urease test is mandatory if a prompt diagnosis is necessary. Microbiological culture can be used in cases of persistent or complicated infection, which may require studies on Helicobacter virulence or antimicrobial susceptibility. Selected cases might demand a combination of several tests. The three tests exhibit a good concordance level for Helicobacter pylori active infection diagnosis.
\end{abstract}

HEADINGS - Gastritis. Helicobacter infections. Urease. Microbiological technique.

\section{INTRODUCTION}

The correct diagnosis and effective treatment of Helicobacter pylori gastric infection are essential in controlling this entity, characterized by its high prevalence worldwide and linked with chronic gastritis, gastric atrophy and cancer. Currently, an optimal method for the diagnosis of Helicobacter pylori active infection (HpAI) does not exist. The methods available have advantages and limitations related to factors such as level of technical difficulty, cost and extensive accessibility in the hospitals. Multiple authors mention the term "recommend" or "ideal" when referring to the sample to be used for diagnosis. However, the circumstances which lead to this type of sample and apply the most recommended diagnostic technique, in many cases are not present in the usual clinical setting. Undoubtedly, the dyspeptic patient requires a diagnosis to guide the treatment and follow-up. The clinical circumstances of the each case, as well as resources available in the local health center, might be necessary consider to adjust the type and number of samples to be taken, as well as the diagnostic method to be select ${ }^{(3)}$.

The purpose of this study was to assess the diagnostic value of endoscopic gastric biopsies used for histopathological evaluation (HE), the urease test (UT) and microbiological culture (MC) to detect the presence of $\mathrm{HpAI}$ in the clinical setting of a gastroenterology department, in order to make recommendations applicable to everyday clinical experience.

\footnotetext{
${ }^{1}$ Laboratorio de Investigaciones Gastrointestinales, Instituto de Investigaciones Biológicas; ${ }^{2}$ Laboratorio de Bacteriología Clínica, Escuela de Bioanálisis; ${ }^{3}$ Postgrado de Gastroenterología, Facultad de Medicina, Universidad del Zulia, Maracaibo, Venezuela.

Correspondence: Dr. Gabriel Arismendi-Morillo - Laboratorio de Investigaciones Gastrointestinales, Instituto de Investigaciones Biológicas - Facultad de Medicina Universidad del Zulia - Maracaibo, Venezuela. E-mail: gabrielarismendi@gmail.com.
} 


\section{METHODS}

\section{Population and sample}

The population comprised all patients with dyspeptic's symptoms attending the gastroenterology department of the Universitary Hospital of Maracaibo, in Zulia State, Venezuela, between June 2007 and December 2009. Consecutive patients of any gender, ethnicity and age, if they had declared their acceptance to participate in the study, by signing the informed consent, were included. Patients with severe systemic disease, active gastrointestinal bleeding or blood in the stomach cavity, antibiotic therapy anti-H. pylori in the last 3 months and treatment with $\mathrm{H}_{2}$ inhibitors and inhibitors of proton pump in the last 15 days were excluded.

All selected patients underwent a complete medical history tabulated and esophagus-gastro-duodenoscopy with biopsy of the mucosa of the gastric body and antrum for HE, MC and UT.

\section{Upper gastrointestinal endoscopy}

This procedure was performed in patients with a minimum of 10 hours of fast, after topical anesthesia of the pharynx and hypopharyngeal and intravenous sedation with midazolam (3-5 mg intravenously) ${ }^{(10)}$. A flexible endoscope was introduced according to the technique previously described ${ }^{(18)}$. Continuous monitoring of vital signs was made. Upon reaching the stomach cavity is systematically reviewed the fundus, the body and gastric antrum. Three endoscopic biopsies of the antrum and body (about $3 \mathrm{~mm}$ in diameter each) were obtained, giving preference to areas with lesions. The samples for microbiological culture and rapid urease test not were covered with blood. The samples were placed in separate vials, previously identified, containing the appropriate medium for each test.

\section{Urease test}

The first biopsy of gastric antrum, it was placed in an Eppendorf tube containing $1.5 \mathrm{~mL}$ of urea agar, prepared according to the procedure previously described and standardized for the population studied ${ }^{(9)}$. The sample was incubated at $35^{\circ} \mathrm{C}$ for up to 2 hours, checking periodically changes the appearance of color in the agar. The test was considered positive when, during the incubation period, did the color change of phenol red indicator contained in the middle, a soft orange or fuchsia pink. The absence of color changes or changes after the first 2 hours was considered a negative result.

\section{Culture for $\boldsymbol{H}$. pylori}

The culture for this organism was prepared from a biopsy of gastric antral mucosa, following the procedure described above $^{(8)}$. Biopsy forceps retired from the endoscope by using a sterile needle, and placed in an Eppendorf tube containing $0.5 \mathrm{~mL}$ of sterile saline as a means of transportation. This was processed in a period not longer than 4 hours after collection. At first, the tissue was cut thinly using a razor blade scalpel on a watch glass sterile. For primary isolation, the sample was place in two enriched culture media (a selective and a non-selective, using Brucella agar base supplemented with sheep blood 5\%). The selective medium was added three antimicrobial agents: vancomycin, trimethoprim, and amphotericin B. Both media were incubated in a moist microaerobic atmosphere $(5 \% \mathrm{O} 2,10 \%$ $\mathrm{CO} 2$ and $85 \% \mathrm{~N} 2$ ) using anaerobic jars and gas generating envelopes Anaerocult $\mathrm{C}^{\circledR}$ (Merck, Darmstadt, Germany), at a temperature of $35^{\circ} \mathrm{C}$. Cultures were followed at 3,5 and 7 days. The identification of the isolates was based on colonial and cellular morphology characteristic of $H$. pylori, and by testing for oxidase, catalase and urease positive.

\section{Histopathological evaluation}

A biopsy of the body and other gastric antrum were fixed in a solution of formaldehyde $10 \%$. Subsequently, the gastric mucosa samples were processed, following the usual steps of dehydration and paraffin embedding, and then proceeding to make serial sections of up to $5 \mu \mathrm{m}$, and stained with hematoxylin-eosin. All specimens were evaluated by the same pathologist in order to identify the presence of H. pylori, according to the morphology described for this organism in histological sections. In all cases, preparations were observed under light microscope at 10X, 40X and 100X (oil immersion). When identified the presence of $H$. pylori, it was designated how scanty, moderate or abundant. The pathologist was unknowledgeable of the clinical features as well as the result of the urease test and microbiological culture, at the time of $\mathrm{HE}$, for each case.

\section{Statistical analysis}

Statistical analysis was carried out by Chi square test and Student $t$ (unpaired samples). $P<0.05$ was considered significant. The concordance of the HE, UT and MC was studied using the Cohen's kappa index of agreement.

\section{RESULTS}

One hundred fifteen cases were studied, 85 female (74\%) and 30 male (26\%). The ages were between 16 and 76 years (38.6 \pm 13.1 years). The HpAI was diagnosed in 77 cases ( $66 \%$ ); the 38 remaining cases $(34 \%)$ of three diagnostic tests were negative. The HpAI were diagnosed in $68.2 \%$ of female cases and $63.3 \%$ of male cases, without statistical differences.

The results for the diagnosis of HpAI with each of the tests, revealed that the $\mathrm{HE}$ of the antrum and body were the test that identified a higher number of cases of HpAI, compared with the UT and MC (Table 1). The difference between the number of positive cases detected by HE vs UT was not statistically significant $(P=0.7)$, since $\mathrm{HE}$ vs MC and UT vs MC were $P<0.0001$ and $P<0.001$, respectively. In eight cases ( $10 \%$ of infected patients), the HpAI was diagnosed only by $\mathrm{HE}$ in the gastric mucosa of the antrum and/or gastric body, whereas the UT was the only test positive in three cases $(4 \%)$ and the MC was the only positive test in one case $(1.3 \%)$. The results of microbiological culture could not be performed in eight cases $(7 \%)$ due to microbiological contamination. 
TABLE 1. Histopathological evaluation, urease test and microbiological culture in cases of Helicobacter pylori active infection

\begin{tabular}{lccc}
\hline $\begin{array}{l}\text { Diagnostic test } \\
\text { HpAI }\end{array}$ & $\begin{array}{c}\text { Histopathological } \\
\text { evaluation* }\end{array}$ & $\begin{array}{c}\text { Urease } \\
\text { test }\end{array}$ & $\begin{array}{c}\text { Microbiological } \\
\text { culture }\end{array}$ \\
\hline Present & $67(87 \%)$ & $61(79 \%)$ & $54(70 \%)$ \\
Absent & $10(13 \%)$ & $16(21 \%)$ & $23(30 \%)$ \\
\hline
\end{tabular}

*Antrum and body biopsies are included

HpAI: Helicobacter pylori active infection

The presence of $H$. pylori in the antral mucosa was established in 55 cases $(71.4 \%)$, while the mucosa of the gastric body it was evident in 49 specimens $(63.6 \%)$ (Figure 1). In 18 patients $(23.3 \%)$, the HpAI was determinates exclusively at the antrum biopsy, whereas in 12 cases $(15.6 \%)$ was observed merely at the body specimen. In 37 cases $(48 \%)$, the HE revealed the presence of the organism in both specimens.

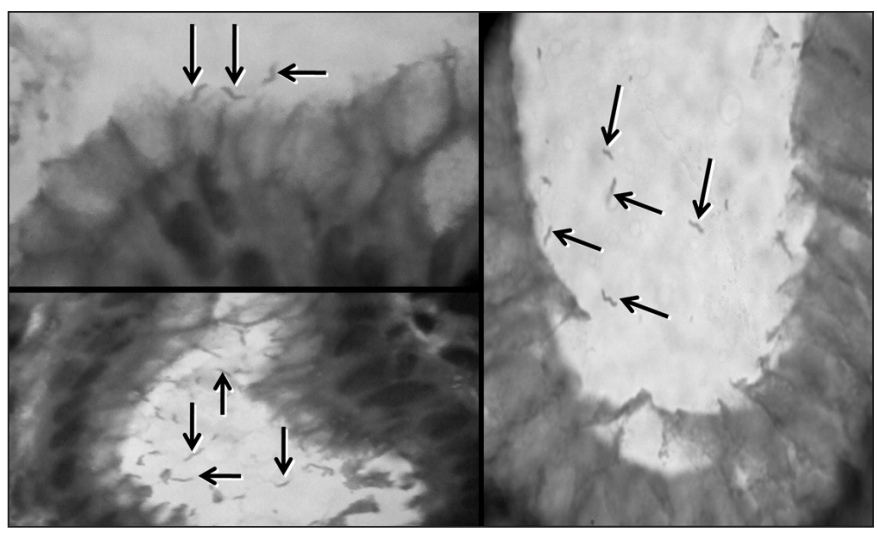

FIGURE 1. Gastric biopsies stained with hematoxylin-eosin. Helicobacter pylori (arrows). 100X oil immersion

General agreement between the results obtained by the combinations of two diagnostic tests was $\sim 80 \%$, with small variations in the value of concurrence between the different combinations, while the agreement between the three tests was $71 \%$. The kappa index of agreement for HE/UT was $0.56, \mathrm{HE} / \mathrm{MC} 0.6$, and UT/MC 0.64 .

\section{DISCUSSION}

The analysis of the results obtained by utilization of three diagnostic methods based on gastric mucosal biopsies obtained by endoscopy, suggests that the HE stained with hematoxylin-eosin has a high diagnostic suitability, consistent with suggested by other authors, in most cases, the HpAI diagnosis can be made in appropriate gastric mucosa

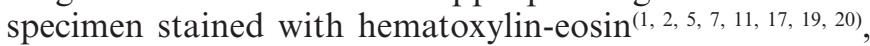
and special stains should be reserved for selected cases ${ }^{(1,}$ 19). The difference to diagnose $\mathrm{HpAI}$ by means the $\mathrm{HE}$ of a single biopsy of the antrum and body mucosa, highlight the importance of obtain at least one specimen in each region of the gastric mucosa, in order to increase significantly $(P<0.001)$ the diagnostic usefulness of the HE. Therefore, at the clinical setting studied, the HE of one of antrum and body biopsy results highly suitability for the HpAI diagnosis. This finding supports the recommendation previously made by other authors ${ }^{(6,13)}$, i.e. two biopsies (one of antrum and one of corpus) reduce the risk of false-negative results of anatomopathologic examination. In addition, several studies with similar number of specimens of gastric biopsies examined, shows a good reproducibility, with good kappa index values ${ }^{(1)}$. Additionally, HE has other implication, the possibility of making the histopathological diagnosis of lesions of the gastric mucosa accompanying the $H$. pylori infection, consequently contributing to a comprehensive view of the complexity of each case, and to make the optimal treatment. This is another reason for recommending the preference of this technique as an excellent diagnostic option in a clinical setting.

In other hand, the histological detection of $\mathrm{HpAI}$ by one pathologist could be considered a limitation. In this work, like on the clinical setting is performed, the histopathological diagnosis of $\mathrm{HpAI}$ is made by one pathologist. However, in this case, the pathologist have experience in the routine histological diagnosis of $H$. pylori infection, and in each case, meticulous examination was carried out. Possibly, this approach allowed that only $5.3 \%$ of $\mathrm{HE}$ were negative for the HpAI, when UT or MC were positive, as well the HE was the only positive test for the $\mathrm{HpAI}$ in $10 \%$ of infected individuals. These findings are in agreed with the reported by Maconi et al. ${ }^{(12)}$, they stated that an experimented pathologist will perform a more accurate search for $H$. pylori.

In relation to the UT, it also showed a high diagnostic capability of HpAI, although it was slightly lower than that of $\mathrm{HE}$, was not significantly different, which be in accord with the described by other authors ${ }^{(2,4,5,11,14)}$. However, the UT only detected the presence of HpAI in $4 \%$ of infected patients, in whom the other two tests failed to diagnose such condition, and does not provide additional information on the status of the gastric mucosa. Therefore, in addition to the adequate diagnostic capacity, the fundamental advantage of the UT is the possibility of a rapid and economical test, therefore, it is considered an invasive method of choice in patients whose identification could change or HpAI guide immediate treatment $\mathrm{t}^{(5,15)}$.

The MC is the method had lower diagnostic precision, which was significantly lower than the HE and the UT. The $\mathrm{MC}$ is a laborious method, with some technical difficulties, a cost and processing time than those of UT and HE, so that there is a tendency not to use it as a routine diagnostic method. In this study, contamination of $\mathrm{MC}$ in $7 \%$ of the cases revealed one of the technical difficulties that this test may imply. The presence of contamination in $H$. pylori cultures, derived from gastric biopsies, can reduce the sensitivity of this method ${ }^{(16)}$. Endoscopic procedures seem to be a source of contamination by several microorganisms ${ }^{(16)}$. Ribeiro et al. ${ }^{(16)}$ stated that the risk of transmission of microorganisms was not detectable when sterilized biopsy forceps and stringent disinfection standards were employed. In spite of these potential limitations, despite one benefit is that the MC has 
the ability to isolate the strain of $H$. pylori involved in each case, allowing for further testing susceptibility to antimicrobial or molecular tests to identify strains of high virulence, tools that could be useful in cases of severe infection, persistent or complicated.

Finally, the analysis of kappa index of agreement between HE/UT (0.56), HE/MC (0.6), and UT/MC (0.64), demonstrate a good concordance level for HpAI diagnosis. This aspect is important for the evaluation of the clinical requirements of each case, as well as for the test-accessibility on the clinical setting in which the patient attends, which would help in the comprehensive assessment of each case. Inconsistencies between the HE, UT and MC could be linked to the irregular distribution, focal or segmental $H$. pylori on gastric mucosa. This difficulty could be mitigated by the analysis of several biopsy specimens or by using other diagnostic tests.
In summary, the HE and UT are the most valuable biopsies-diagnostic tests to identify the HpAI. The use of HE is suggested when, in addition $\mathrm{HpAI}$ diagnose, it is essential to determine the histopathology of gastric lesions, and the UT, in cases that an immediate diagnosis is necessary. The CM would be suitable only in cases of persistent or complicated infection, in which susceptibility testing to antimicrobial agents and/or the detection of highly virulent strains may help to clarify the clinical picture or to adjust their therapeutic management.

\section{ACKNOWLEDGMENTS}

Research partially funded by Consejo de Desarrollo Científico y Humanístico de la Universidad del Zulia (CondesLuz, Venezuela); Project \# CC-0627-04. To Nivia Abreu and Mary Nelly Ramos for their laboratorial support.

Arismendi-Morillo G, Hernández I, Mengual E, Fuenmayor A, Romero G, Lizarzábal M. Comparação de três métodos baseados em biopsias gástricas endoscópicas para o diagnóstico da infecção ativa pelo Helicobacter pylori em um ambiente clínico. Arq Gastroenterol. 2011;48(3):190-4.

RESUMO - Contexto - O diagnóstico correto e o tratamento eficaz da infecção pelo Helicobacter pylori são essenciais no controle desta infecção. Objetivo - Comparar o valor de três testes de diagnóstico baseado em biopsias gástricas endoscópicas: avaliação histopatológica com hematoxilina-eosina (H-E), teste da urease e cultura microbiológica para a detecção da infecção ativa pelo H. pylori, com a finalidade de recomendações para a clínica diária prática. Métodos - Biopsias gástricas de 115 pacientes ( 85 mulheres e 30 homens) foram obtidas por endoscopia digestiva alta e estudadas por avaliação histopatológica com H-E (antro-corpo), teste de urease em 2 horas (antro) e cultura microbiológica (antro). Resultados - Infecção ativa pelo $H$. pylori foi diagnosticada em $67 \%$ dos pacientes e detectada pela avaliação histopatológica com H-E, pelo teste de urease e pela cultura microbiológica em $87 \%, 79 \%$ e 70\% dos casos positivos, respectivamente. Houve diferenças significativas quando a avaliação histopatológica com H-E e o teste rápido de urease quando comparadas com a cultura microbiológica $(P<0,01)$. Não houve diferença significativa entre a avaliação histopatológica com H-E e o teste de urease $(P=0,7)$. O índice kappa para avaliação histopatológica com H-E/teste de urease foi de 0,56 , avaliação histopatológica com H-E/cultura microbiológica 0,6, e teste de urease/cultura microbiológica 0,64. Conclusões - Em condições similares ao estudado, avaliação histopatológica com H-E e teste de urease são os testes mais recomendados para o diagnóstico de infecção ativa pelo $H$. pylori com base em biopsias endoscópicas. A avaliação histopatológica com H-E é essencial quando exigido o estudo de lesões gástricas. O teste de urease é obrigatório no caso de diagnóstico precoce rápido. A cultura microbiológica pode ser usada em casos de infecção persistente ou complicada, que podem exigir estudos sobre a virulência ou susceptibilidade do Helicobacter aos antimicrobianos. Os casos selecionados podem exigir a combinação de vários testes. Os três testes apresentam bom nível de concordância para o diagnóstico da infecção ativa pelo H. pylori.

DESCRITORES - Gastrite. Infecções por helicobacter. Urease. Técnicas microbiológicas.

\section{REFERENCES}

1. Aydin O, Egilmez R, Karabacak T, Kanik A. Interobserver variation in histopathological assessment of Helicobacter pylori gastritis. World J Gastroenterol. 2003;9:2232-5.

2. Barmejo San José F, Boixeda de Miguel D, Gisbert JP, Martin de Argila de Prados C, Sanz Sacristán JM, Defarges Pons V, Moreno Almazán L, García Plaza A Efficacy of four widely used techniques of the diagnosis of Helicobacter pylori infection in gastric ulcer disease. Rev Clin Esp. 2000;200:475-9.

3. Burette A. How (who?) and when to test or retest for H. Pylori. Acta Gastroenterol Belg. 1998;61:336-43

4. Caetano A, Felix VN, Coimbra FT, Ganc AJ. [Helicobacter pylori and peptic disease: comparative study of the diagnostic methods]. Arq Gastroenterol. 2008;45:255-7.

5. Castro-Fernández M, Sánchez-Muñoz D, García-Díaz E, Miralles-Sanchiz J, Vargas-Romero J. Diagnóstico mediante endoscopia de la infección por Helicobacter pylori en pacientes con úlcera gastroduodenal y hemorragia digestiva: test rápido de ureasa e histología. Rev Esp Enferm Dig. 2004:96:395-401.

6. De Korwin J. [Avantages and limitations of diagnostic methods for H. Pylori infection]. Gastroenterol Clin Biol. 2003;27:380-90.
7. Fallone CA, Loo VG, Lough J, Barkun AN. Hematoxylin and eosin staining of gastric tissue for the detection of Helicobacter pylori. Helicobacter. 1997:2:32-5.

8. Fuenmayor A, Cavazza M, Beltrán de Luengo H, Gallegos B, Inciarte A Botero L, Avila M. Infección por Helicobacter pylori en pacientes con patología gastrointestinal benigna. Rev Soc Venez Microbiol. 2002;22:27-31.

9. Fuenmayor A, Hernández I, Paz A, Cavazza ME, Lizarzábal M. Nuevas evidencias sobre la utilidad diagnóstica de una fórmula no comercial para la detección de la actividad de ureasa de Helicobacter pylori en biopsias gástricas. Kasmera. 2006;34:40-52.

10. Keeffe EB, O’Connor KW. 1989 A/S/G/E survey of endoscopic sedation and monitoring practices. Gastrointest Endosc. 1990;36:s13-8.

11. Kullavanijaya P, Thong-Ngam D, Hanvivatvong O, Nunthapisud P, Tangkijvanich P, Suwanagool P. Analysis of eigth different methods for the detection of Helicobacter pylori infection in patients with dyspepsia. J Gastroenterol Hepatol 2004:19:1392-6.

12. MaConi G, Vago L, Galletta G, Imbesi V, Sangaletti O, Parente F, Cucino C, Bonetto S, Bianchi Porro G. Is routine histological evaluation an accurate test for Helicobacter pylori infection? Aliment Pharmacol Ther. 1999;13: 327-31. 
13. Monés J, Gisbert JP, Borda F, Domínguez-Muñoz E; Grupo Conferencia Española de Consenso sobre Helicobacter pylori. Indications, diagnostic test and Helicobacter pylori erradication therapy. Recommendations by the $2^{\text {nd }}$ Spanish Consensus Conference [online]. Rev Esp Enferm Dig. 2005;97: 348-74.

14. Muñoz E, Corcuera MT, Roldán M, Gómez F, Picazo A, Baquero M, Alonso MJ Comparative study of microbiological and histopathological techniques used for the detection of Helicobacter pylori. Eur J Histochem. 1998;42:297-302.

15. Onders RP. Detection methods of Helicobacter pylori: accuracy and costs. Am Surg. 1997;63:665-8.

16. Ribeiro ML, Godoy AP, Benvengo YH, Ecclissato CC, Mendonça S, Pedrazzoli J $\mathrm{Jr}$. The influence of endoscopic procedures upon the contamination Helicobacter pylori cultures. Arq Gastroenterol. 2004;41:100-3.
17. Rotimi O, Cairns A, Gray S, Moayyedi P, Dixon MF. Histological identification of Helicobacter pylori: comparison of staining methods. J Clin Pathol. 2000;53:756-9.

18. Waye J, Geenen J, Fleischer D, editores. Techniques in therapeutic endoscopy. New York: Gower Medical Publishing; 1987.

19. Wright CL, Kelly JK. The use of routine special stains for upper gastrointestinal biopsies. Am J Surg Pathol. 2006;30:357-61.

20. Yap I, Kung JS, Wee A, Tay HH, Guan R, Ho B, Kang JY. Comparison of culture and histology for the identification of Helicobacter pylori in endoscopic biopsies. Ann Acad Med Singapore. 1990;19:354-6.

Received 28/1/2011 Accepted 19/5/2011. 